\title{
THE LESSER PROMINENT FACTORS CONTRIBUTING TO MALAYSIAN GRADUATES EMPLOYABILITY
}

\author{
ANEES JANEE ALI ${ }^{1 *}$, NOORDEEYANY KAMAL SURADEE ${ }^{1}$, UBEDULLAH MENON ${ }^{1}$, JAMSHED \\ KHALIL $^{2}$, NORDIANA MOHD NORDIN ${ }^{3}$, MAHISWAREN SELVANATHAN ${ }^{4}$, NURUL HIDAYAH ${ }^{5}$, \\ MASS HAREEZA ALI ${ }^{6}$, and YAZRINA YAHYA ${ }^{7}$ \\ ${ }^{1}$ School of Management, Universiti Sains Malaysia \\ ${ }^{2}$ Government College University Faisalabad, Pakistan \\ ${ }^{3}$ Faculty of Information Management, Universiti Teknologi MARA \\ ${ }^{4}$ National Higher Education Research Institute (IPPTN), Universiti Sains Malaysia \\ ${ }^{5}$ Universitas Mercu Buana, Jakarta \\ ${ }^{6}$ Universiti Putra Malaysia \\ ${ }^{7}$ Universiti Kebangsaan Malaysia \\ *aneesali@usm.my
}

\begin{abstract}
Malaysian graduates, both undergraduates and postgraduates are having some difficulties in getting employed upon their graduation. This issue has been a debate since many years ago especially in the Covid-19 pandemic, jobs less offered in the market for the graduates to grab. This research looks at a few less prominent factors of employability among 171 Malaysian graduates who have graduated within the last three (3) years and currently employed. Through SPSS statistical analysis, the research found that age, gender, level of study, staying at campus hostel and field of study directly give effect on graduates' employability. The younger the age of the respondents, being male graduates, being undergraduates, staying at the hostel campus with campus life experience and being from management/social sciences background were found to be factors that contribute for Malaysian graduates' employability.
\end{abstract}

Keywords: Malaysian graduates, graduates’ employability

\section{INTRODUCTION}

"More and More Graduates are Facing Unemployment in Malaysia" - one is bound to believe that the future of employment seems bleak, said the Malaysia Education Ministry of Higher Education Department (https://www.nst.com.my/news/nation/2020/02/566731/ graduate-employability-priority-education-ministry). This headline has created so much fuss among the fresh graduates in Malaysia considering that the main reason for them furthering their studies at tertiary level is in order to get a good job in the future.

Ministry of Higher Education Malaysia conducts a survey of graduates' employability on yearly basis to check on graduates' employability in Malaysia upon graduates' graduation. The expectation of the Ministry is to get a minimum of $75 \%$ freshly graduates to be employed upon their graduation. The employability of Malaysian graduates has dropped by $1.8 \%$ in 2020 (84.4\%) compared to 2019 (86.2\%) (https://www.malaymail. com/news/malaysia/2021/03/12/higher-educationministry-malaysian-graduates-employability-down-to$84.4 \mathrm{pc} / 1957347)$. The concentration of the present study will be on the survey of the year 2019 and 2020 when the Covid-19 pandemic hits Malaysia and the whole world in the beginning of 2020. Malaysia started the first MCO (Movement Control Order) in March 2020. Due to this $\mathrm{MCO}$, many companies and factories are badly affected, and they had to close their operations for months. Due to this situation, any employees were laid off and some had some cut in their monthly salary. Until this article is written (in August 2021), the MCO is still in action and many more employees and companies are affected. Since companies are not able to operate at full capacities, the chances to hire new employees are almost zero. This has given a huge impact on the graduates' employability which is indicated in Tables 1.1. 1.2 and 1.3 below (Ministry of Higher Education, https:/great.mohe.gov.my/Statistik)

Table 1., 2 and 3 below indicate the employability of Malaysian graduates in 2019 and 2020. All the statistics shown in these three tables indicate a declining trend among the Malaysian graduates' employability.

Table 1. Employability rate of Malaysian graduates according to institution

\begin{tabular}{lcc}
\hline $\begin{array}{c}\text { Higher Education Institution } \\
\text { (HEI) }\end{array}$ & $\mathbf{2 0 1 9}$ & $\mathbf{2 0 2 0}$ \\
\hline Public Universities & $87.8 \%$ & $86.7 \%$ \\
Private Universities & $79.0 \%$ & $79.4 \%$ \\
Polytechnics & $96.7 \%$ & $91.4 \%$ \\
Community College & $97.8 \%$ & $94.2 \%$ \\
Vocational College & $97.4 \%$ & $81.6 \%$ \\
\hline
\end{tabular}

Source: Malaysia Ministry of Higher Education (https://great.mohe. gov.my/Statistik)

Table 1.1 shows that among Malaysian graduates from the 20 (twenty) Public Universities in Malaysia, employability dropped from $87.8 \%$ to $86.7 \%$. The same with graduates from Polytechnics, Community College and Vocational College showed a decline trend in employability among them. Only graduates from the Private Universities in Malaysia show an increase in employability but only with a mere increase of $0.4 \%$. 
Table 2 shows the employability rate in 2019 and 2020 based on the educational level of the graduates. For $\mathrm{PhD}$ and Master graduates show an increase trend in employability but for the First-degree graduates, a sharp decrease is shown in their employability, that is a decrease of $1.6 \%$. This is a serious matter for the graduates with a first-degree holder since they are in the group of no working experience and the chances for them to be employed will be lesser in the Covid-19 pandemic era.

Table 2. Employability rate of Malaysian graduates according to the level of study

\begin{tabular}{lcc}
\hline \multicolumn{1}{c}{ Level of Study } & $\mathbf{2 0 1 9}$ & $\mathbf{2 0 2 0}$ \\
\hline PhD & $88.0 \%$ & $89.8 \%$ \\
Master & $89.8 \%$ & $90.5 \%$ \\
First-degree & $83.7 \%$ & $82.1 \%$ \\
\hline
\end{tabular}

Source: Malaysia Ministry of Higher Education (https://great.mohe. gov.my/Statistik)

Table 3 indicates the employability among Malaysian graduates in 2019 and 2020 based on the field of studies. Graduates from all field of studies, except Education, shows a serious declining trend. Example for Engineering, the employability dropped from $90.1 \%$ to $86.5 \%$ (3.6\% decrease), for Science, Mathematics and Computer Science, the employability dropped from $87.2 \%$ to $85.3 \%$ (1.9\% decrease), Health and wellbeing indicates a drop of $1.7 \%$, Social sciences, business and law indicates a drop of $0.7 \%$, Arts indicates a drop of $2.5 \%$, Arts and Humanities indicates a drop of $2.2 \%$ and Agriculture and Veterinary indicates a drop of 3.3\%. Among these field, graduates from the Engineering field indicates the biggest dropped in their employability. Only graduates from the field of Educations shows an increase trend in employability $(3.8 \%)$. The data summarised that there is a general trend of decrease in employability among Malaysian graduates across all field of study. This decreasing trend in employability most probably due to the Covid-19 pandemic that has caused many businesses and companies, economy wise, are affected badly.

Table 3. Employability rate of Malaysian graduates according to field of study

\begin{tabular}{lcc}
\hline Field of Study & $\mathbf{2 0 1 9}$ & $\mathbf{2 0 2 0}$ \\
\hline $\begin{array}{l}\text { Engineering, Manufacturing and } \\
\text { Construction }\end{array}$ & $90.1 \%$ & $86.5 \%$ \\
Science, Mathematics, and Computer & $87.2 \%$ & $85.3 \%$ \\
Science & & \\
Health and Wellbeing & $86.1 \%$ & $84.4 \%$ \\
Social Science, Business, and Law & $84.5 \%$ & $83.8 \%$ \\
Education & $79.2 \%$ & $83.0 \%$ \\
Services & $85.0 \%$ & $82.5 \%$ \\
Arts and Humanities & $83.4 \%$ & $81.2 \%$ \\
Agriculture and Veterinary & $84.5 \%$ & $81.2 \%$ \\
\hline
\end{tabular}

Source: Malaysia Ministry of Higher Education (https://great.mohe. gov.my/Statistik)
The study of the Ministry of Higher Education Malaysia also asked the graduates who are still unemployed. Among the reasons given why they were still unemployed are still looking for a job $(72.8 \%)$, resting/ taking a holiday (6.7\%), waiting for results to further studies $(6.0 \%)$, responsibilities to family $(4.5 \%)$ and job offered is not suitable with qualifications $(2.4 \%)$.

\section{SIGNIFICANCE OF THE STUDY}

This study is important as it indicates the other factors, that are less famous, that are important in contributing to the employability of Malaysian graduates. The findings of this study will shed lights on the factors that have not been studied before in the field of employability such as age, gender, level of study, experiences of staying at campus hostel during study, and field of study. The findings of the study are important for the Ministry of Higher Education and higher level of education institutions to take note so as to improve the employability of graduates. In addition, current students of higher education institutions should identify the importance of the above factors in assisting them in getting employed in the future.

\section{RESEARCH OBJECTIVES}

There are five main objectives of the present research which are:

i. To study the relationship between age and graduates' employability

ii. To examine the relationship between gender and graduates' employability

iii. To examine the relationship between level of study and graduates' employability

iv. To examine the relationship between experiences of staying at campus hostel and graduates' employability

v. To examine either field of study has relationship with graduates' employability

\section{LITERATURE REVIEW AND HYPOTHESES}

While there are a few previous researchers who study on employability by using more prominent factors, the present study uses fewer famous factors/indicators that contribute to the employability among Malaysian graduates. Among the factors/indicators are age, gender, level of study, experiences of studying overseas, staying at campus hostel during study, field of study, being active in extracurricular activities, and participating as committee members in organising programmes/projects/events at national and international levels.

\section{Age and Graduate Employability}

The link between employability and age are still in mixed arguments and empirical results. On the other hand, keeping up with the competencies and abilities needed to remain in the workforce seems to be more challenging for older employees than it appears to be for younger employees ( $\mathrm{Ng} \&$ Feldman, 2012). It was 
discovered that older employees were less likely to be hired by organizations' recruiters because they were seen as less adaptive to new technology, less trainable, and less engaged in technological development (Gringart, Eyal, Helmes, \& Speelman, 2005). As a result of these preconceptions, older graduates may face lower hiring rates, less chances for personal growth, and more difficult to remain employed. Importantly, these results concern subjective perspectives on employability, which may or may not be linked to the other indicators we focus on in this study.

Similarly, Ibok (2013) discovered that age had a substantial impact on the development of employable skills among students in Akwa Ibom State. Okwilagwe and Falaye (2010), on the other hand, observed no age differences in the development of employable abilities. A study done by Idaka and Uzoechi (2016) Showed that students in the age range of 21-23 years outperformed those in age ranges of 18-20 years and above in collaboration abilities. More specifically, students aged 24 and above performed better than younger students (18-20 years). According to few studies, one's employability may improve as they grow older. For example, Froehlich, Segers, \& Van den Bossche (2014) discovered that chronological age had modest positive impacts on occupational competence and corporate sense. They claimed that chronological age is a poor indication on its own, and that additional explanatory mediators for the connection between age and employment must be discovered. Aubert, Caroli, \& Roger (2006) explained one such mediator by pointing out that in France, the older workforce makes up a lower percentage of businesses in growing industries. Older employees seem to be concentrated in decreasing industries, which may lead to a loss of relevant skills and, as a result, employability.

H1: Age is significantly related to graduates' employability

\section{Gender and Graduate Employability}

In terms of communication skills, planning and organization, self-management, decision making, computer competence, and overall employability abilities, male students outperformed female students (Uzoechi, 2015). Females, on the other hand, are better in collaboration, problem solving, initiative, and entrepreneurship. In contrast, Dominic and Fulgence (2019) found no disparities in employability abilities between male and female students across all sub-variables.

H2: Gender is significantly related to graduates' employability

\section{Level of study and Graduate Employability}

The level of study attained by people play a vital role in their chances of getting job. With the higher level of study that a student has, the level of specification of certain knowledge is higher compared to students who has lower level of study. Therefore, the higher level of study will give better chances for graduates to be employed. Thus, the following hypothesis was developed.

H3: Level of study is positively related to graduates' employability

\section{Experience of staying in campus hostel and Graduate Employability}

Living away from home for an extended length of time leaves students with some valuable experiences. Students learn to live independently and to compromise with other students in this new way of life. Financial problems, adjustment challenges, personal powerlessness, changes in eating and sleeping habits, and a variety of other issues confront students living in hostels. According to Iftikhar and Ajmal (2015), hostel students will have greater empathy, altruistic conduct, and emotional stability. These challenges and difficulties faced by students while staying in campus hostel will help them in preparing themselves before entering the work world, another phase of ambiguity and surrounded by strangers.

H4: Experience of staying in campus hostel is positively related to graduates' employability

\section{Field of Study and Graduate Employability}

Stojanova and Blaskova (2014) reported that a total of $60 \%$ of students with the field of study in economics and humanities outnumbers the absorption opportunities of labour market. In contrast, graduates in technical and scientific sciences reported minimal difficulties in obtaining job and rated it as easy. Trends in socioeconomic inequality and intergenerational social mobility are influenced by changes in the labour market value of areas of study (Klein, 2016). Klein (2016) stated, from a demand-side viewpoint, although technology advances have increased demand for high-skilled labour, certain areas of study may have benefited more significantly from these occupational shifts in terms of the availability of suitable graduate employment than others. In terms of occupational achievement, certain field of study such as sciences, technology, economics and mathematics may have benefitted more from these compositional changes such as humanities, arts, and social work (Klein, 2016).

H5: Field of study has significant relationship with graduates'employability

\section{METHODOLOGY AND METHODS}

Malaysian graduates, both undergraduates and postgraduate, who had graduated and employed within the last three (3) years upon their graduation were asked to answer a set of questionnaires. This questionnaire asked them a few questions regarding their personal background. The questions asked are:
i. Age
ii. Gender
iii. Level of study 
iv. Have you stayed in the campus hostel before?

v. What is the field of your study?

The questionnaires were distributed from end of June 2021 until early of August 2021, in the height of Covid-19 pandemic cases in Malaysia. Because of the MCO (Movement Control Order) set by the Malaysian government, it was somehow challenging to distribute the questionnaires physically. Therefore, the questionnaire was set in a Google form and later distributed through the platform of WhatsApp. This platform was used since WhatsApp is the most famous mean of communication among people in Malaysia.

Through personal contacts of the researchers', that is, the former students of the researchers, the questionnaires were sent through WhatsApp. Via this WhatsApp platform, the snowball effect is applied in which the former students were asked to share the questionnaires with their friends throughout Malaysia who have graduated within the last three (3) years.

\section{RESULTS AND DISCUSSION}

\section{Demographic Information of the Respondents}

There were 171 respondents in this study, of which all of them were Malaysian graduates who had graduated within the last three (3) years and currently employed. The respondents had studied in the 20 public universities in Malaysia. Table 4 below shows the demographic data of the respondents.

Table 4 Demographic Data of the Respondents

\begin{tabular}{lcc}
\hline \multicolumn{1}{c}{ Variables } & $\boldsymbol{N}$ & $\begin{array}{c}\text { Percentage } \\
(\mathbf{\% )}\end{array}$ \\
\hline Age & 33 & 19.88 \\
$20-22$ & 77 & 45.00 \\
$23-25$ & 32 & 18.70 \\
$26-28$ & 6 & 3.50 \\
$29-30$ & 22 & 12.90 \\
Above 30 & & \\
\hline Gender & 46 & 26.90 \\
Male & 125 & 73.10 \\
Female & & \\
\hline Level of Study & 133 & 77.70 \\
Undergraduate & 31 & 18.10 \\
Postgraduate (Master) & 7 & 4.10 \\
PhD & & \\
\hline Stayed at Hostel & 159 & 93.00 \\
Yes & 12 & 7.00 \\
No & & \\
\hline Field of Study & 37 & 21.64 \\
Pure Science & 17 & 9.94 \\
Pure Arts & 117 & 68.42 \\
Management/Social science & & \\
\hline
\end{tabular}

\section{Data Analysis Plan and Results}

The present study investigated the relationship between demographic variables and graduate employability through a simple linear regression (Sekaran, 2003). The association of the categorical variable with the continuous variable was tested via creating dummy variables in the SPSS. The present study examined the significance of proposed relationships with the critical value of 1.64 at a $5 \%$ error probability. The following tables discuss the regression results in detail.

Table 5. Regression Results (Age)

\begin{tabular}{|c|c|c|c|c|c|c|}
\hline \multirow{2}{*}{\multicolumn{2}{|c|}{$\begin{array}{c}\text { Model } \\
\text { B }\end{array}$}} & \multicolumn{2}{|c|}{$\begin{array}{c}\text { Unstandardized } \\
\text { Coefficients }\end{array}$} & \multirow{2}{*}{$\begin{array}{l}\text { Standardized } \\
\text { Coefficients }\end{array}$} & \multirow[b]{2}{*}{ t-value } & \multirow{2}{*}{ P value } \\
\hline & & $\begin{array}{l}\text { Std. } \\
\text { Error }\end{array}$ & Beta & & & \\
\hline \multirow[t]{5}{*}{1} & $\begin{array}{l}20-22 \\
\text { year }\end{array}$ & 3.966 & .124 & & 31.948 & $\mathrm{p}<0.01$ \\
\hline & $\begin{array}{l}23-25 \\
\text { year }\end{array}$ & -.202 & .148 & -.142 & -1.366 & $\mathrm{p}>0.01$ \\
\hline & $\begin{array}{l}26-28 \\
\text { year }\end{array}$ & -.155 & .177 & -.085 & -.878 & $\mathrm{p}>0.01$ \\
\hline & $\begin{array}{l}29-30 \\
\text { year }\end{array}$ & -.403 & .316 & -.105 & -1.275 & $\mathrm{p}>0.01$ \\
\hline & $\begin{array}{l}\text { Above } \\
30 \\
\text { year }\end{array}$ & -.003 & .196 & -.001 & -.014 & $\mathrm{p}>0.01$ \\
\hline
\end{tabular}

The results in Table 5 reveals the significant association between participants' age range 20-22 and graduate employability ( $\mathrm{t}=31.94, \mathrm{p}<0.01)$. However, the relationship of other age brackets with graduate employability was not found significant (Refer to Table 1.5). It means the participants who were young have significant chances of employability in the Malaysian market.

Table 6. Regression results (Gender)

\begin{tabular}{ccccrcc}
\hline \multirow{2}{*}{$\begin{array}{c}\text { Model } \\
\text { B }\end{array}$} & \multicolumn{2}{c}{$\begin{array}{c}\text { Unstandardized } \\
\text { Coefficients }\end{array}$} & $\begin{array}{c}\text { Standardized } \\
\text { Coefficients }\end{array}$ & t-value & $\begin{array}{c}\text { P } \\
\text { value }\end{array}$ \\
\cline { 2 - 3 } & & $\begin{array}{c}\text { Std. } \\
\text { Error }\end{array}$ & Beta & & & \\
\hline 1 & Male & 3.917 & .105 & & 37.303 & $\mathrm{p}<0.01$ \\
& Female & -.119 & .123 & -.074 & -.970 & $\mathrm{p}>0.01$ \\
\hline \multicolumn{2}{c}{ a. Dependent Variable: Graduate Employability } & & \\
\hline
\end{tabular}

The findings in Table 6 demonstrated the relationship between gender and graduate employability. The results revealed a significant relationship between gender (male) and graduate employability in Malaysia $(t=37.30$, $\mathrm{p}<0.01$ ). Further, the relationship between gender (female) and graduate employability was not found significant. It means male graduates have better employability options in Malaysia than females.

Table 7. Regression results (Level of study)

\begin{tabular}{|c|c|c|c|c|c|c|}
\hline & Model & $\begin{array}{r}\text { Unstan } \\
\text { Coeff } \\
\end{array}$ & $\begin{array}{l}\text { ardized } \\
\text { ients }\end{array}$ & Standardized & t-value & $\mathbf{P}$ \\
\hline & B & $\begin{array}{l}\text { Std. } \\
\text { Erroror }\end{array}$ & Beta & Coefficients & t-value & value \\
\hline 1 & $\begin{array}{l}\text { Undergraduate } \\
\text { level }\end{array}$ & 3.785 & .062 & & 61.383 & $\mathrm{p}<0.01$ \\
\hline & $\begin{array}{l}\text { Master } \\
\text { Degree }\end{array}$ & .215 & .142 & .117 & 1.514 & $\mathrm{p}>0.01$ \\
\hline & $\mathrm{PhD}$ & .143 & .276 & .040 & .520 & $\mathrm{p}>0.01$ \\
\hline
\end{tabular}

Table 7 explicates the regression results of the level of study with the respondents' graduate employability. 
The findings revealed a significant association between the undergraduate level of study and graduate employability $(\mathrm{t}=61.38, \mathrm{p}<0.01)$. Additionally, the results showed an insignificant relationship between master's degree and employability of respondents $(t=1.514, \mathrm{p}>0.01)$. Finally, the results also revealed the insignificant relationship between respondents' $\mathrm{PhD}$ Degree and their employability $(\mathrm{t}=0.520, \mathrm{p}>0.01)$. It means the participants with an undergraduate level of study enjoy better employability options in the Malaysian market.

Table 8. Regression Results (Experiences of staying at the campus hostel)

\begin{tabular}{|c|c|c|c|c|c|c|}
\hline & & Unstanc & rdized & & & \\
\hline & Model & Coeff & ents & Standardized & t-valu & Pyalue \\
\hline & B & $\begin{array}{c}\text { Std. } \\
\text { Error }\end{array}$ & Beta & Coefficients & I-vaiue & Pvalue \\
\hline 1 & With & 3.830 & .057 & & 67.619 & $\mathrm{p}<0.01$ \\
\hline & Campus & & & & & \\
\hline & Study & & & & & \\
\hline & Experience & & & & & \\
\hline & $\begin{array}{l}\text { Without } \\
\text { campus }\end{array}$ & .004 & .214 & .001 & .017 & $\mathrm{p}>0.01$ \\
\hline & Study & & & & & \\
\hline & Experience & & & & & \\
\hline & Dependent Va & iable: $\mathrm{Gr}$ & uate $\mathrm{E}$ & ployability & & \\
\hline
\end{tabular}

The findings in Table 8 demonstrates the relationship between experiences of staying at campus hostel with the graduates' employability. The results revealed the significant association of campus study experiences with graduates' employability in Malaysia $(\mathrm{t}=67.61, \mathrm{p}<0.01)$. On the other side, those participants who were deprived of campus study exposure showed an insignificant relationship with graduate employability.

Table 9 Regression Results (Field of Study)

\begin{tabular}{|c|c|c|c|c|c|c|}
\hline & \multirow{2}{*}{$\begin{array}{c}\text { Model } \\
\text { B }\end{array}$} & \multicolumn{2}{|c|}{$\begin{array}{c}\text { Unstandardized } \\
\text { Coefficients }\end{array}$} & \multirow{2}{*}{$\begin{array}{c}\text { Standardized } \\
\text { Coefficients }\end{array}$} & \multirow{2}{*}{ t-value } & \multirow{2}{*}{$\begin{array}{c}\text { P } \\
\text { value }\end{array}$} \\
\hline & & $\begin{array}{c}\text { Std. } \\
\text { Error }\end{array}$ & Beta & & & \\
\hline \multirow[t]{4}{*}{1} & Management/ & & & & & \\
\hline & $\begin{array}{l}\text { Social } \\
\text { Science }\end{array}$ & 3.820 & .065 & & 58.709 & $\mathrm{p}<0.01$ \\
\hline & Pure Science & .259 & .175 & .115 & 1.478 & $\mathrm{p}>0.01$ \\
\hline & Pure Arts & -.096 & .140 & -.054 & -.690 & $\mathrm{p}>0.01$ \\
\hline \multicolumn{7}{|c|}{ a. Dependent Variable: Graduate Employability } \\
\hline
\end{tabular}

The results in Table 1.9 demonstrates the association of the field of studies with the graduates' employability. The results unveiled the significant association of Management/ Social Science Studies with graduates' employability in Malaysia $(t=58.70, p<0.01)$. Contrary, the association of the remaining two fields, namely Pure Science and Pure Arts, with graduates' employability was not found significant. It means the Management/Social Science graduates have better employability options in the Malaysian Market.

\section{CONCLUSION}

Findings of the present study indicates that all of these fewer dominant factors are strong predictors of graduates' employability in Malaysia. Firstly, the age factor. Firstly, the present study found that the younger the respondents, the better their chances of getting jobs. This finding agrees with the findings of $\mathrm{Ng}$ and Feldman (2012) and Gringart, Eyal, Helmes, and Speelman (2005) who found that the younger the candidates, the better chances they have for employment because they are more adaptive to technology. Secondly, the present study found that males have high chances of getting employed, which is parallel with the finding of Uzoechi (2015). This probably due to the nature of the jobs of the graduates who involved in this study. Thirdly, the level of study of the graduates. The present study hypothesized that the higher the study level, the better chances the graduates to be employed. However, the finding of the study shows the opposite. The undergraduates had better chances of getting employed compared to master and $\mathrm{PhD}$ graduates. This probably because companies prefer the undergraduates since they are easy to be mould into the company's working culture. Fourthly is having experience of staying at campus hostel during the study. As expected, graduates who had campus study experience had better chances to be employed. In Malaysia, it is competitive to stay at the hostel since the demand is very high and the place is limited. Students need to be active with activities and collect certain number of points in order to be offered a room at the hostel campus. In order to collect points, students need to be active and participate in many co-curricular activities throughout the year.

Lastly, as predicted, graduates' field of study shows as an indicator of graduates' employability. The present study found that graduates in Management/Social sciences have better chances of getting employed compared to the graduates with Pure Science and Pure Art background. The present study can conclude that even though the five factors examined are less prominent in predicting graduates' employability, they in fact, do influence graduates' employability. It is highly recommended for graduates to take note of these factors since they will influence their employability in the future.

\section{Recommendations}

The present study asked the respondents a few questions regarding their background while they were studying at the Malaysia public universities. The present study recommends future research to study further either by participating in programmes either at national or international level will contribute to their employability. The present study also did not ask the name of the jobs that the graduates were working, which may give effect to the finding on gender factor. In addition, a better in-depth measurement should be developed in order to test the variables involved in the present study.

\section{ACKNOWLDEGEMENT}

Researchers would like to acknowledge our gratitude to Universiti Sains Malaysia for the Research University 
grant (RUI:1001/PMGT801 6084) for making this research and publication possible. Thank you.

\section{REFERENCES}

Aubert, P., Caroli, E., \& Roger, M. (2006). New technologies, organisation and age: Firm-level evidence. The Economic Journal, 116(509), 73-93. https://doi.org/10.1111/j.1468-0297.2006.01065.x

Dominic, T., \& Fulgence, K. (2019). Gender differences in enhancing students' employability skills. ORSEA Journal, 9, 57-71.

Froehlich, D. E., Segers, M. S. R., \& Van den Bossche, P. (2014). Learning to stay employable. Career Development International, 19, 508-525.

Gringart, Eyal, Helmes, E., \& Speelman, C. P. (2005). Exploring attitudes towards older workers among Australian employees: An empirical study. Journal of Aging and Social Policy, 17, 85-103.

Ibok, E. E. (2013). Evaluation of employability skills acquisition among secondary school students. Unpublished M.Ed Thesis. University of Uyo, Nigeria.

Idaka, I. E., \& Uzoechi, L. I. (2016). Gender, age, and employability skills acquisition among university students in Imo state, Nigeria. International Journal of Innovative Education Research, 4(4), 6-15.

Iftikhar, A., \& Ajmal, A. (2015). A qualitative study investigating the impact of hostel life. International Journal of Emergency Mental Health and Human Resilience, 17(2), 511-515.
Klein, M. (2016). The association between graduates' field of study and occupational attainment in West Germany, 1980-2008. Journal Labour Market Res, 49, 43-58. https://doi.org/10.1007/s12651-0160201-5

Ng, T. W. H., \& Feldman, D. C. (2012). Evaluating six common stereotypes about older workers with metaanalytical data. Personnel Psychology, 65, 821858.

Okwilagwe, E. A., \& Falaye, F. V. (2010). Graduate employability: Assessment of skills mismatch and wait-time of graduates in a Nigerian university. International Journal of Continuing and NonFormal Education, 7(1), 33-53.

Sekaran, U. (2003). Research methods for business: a skill building approach, (4 $4^{\text {th }}$ Edition). John Willey and Sons.

Stojanova, H., \& Blaskova, V. (2014). The role of graduates' field of study and its impact on the transition to working life. Procedia Economics and Finance, 12, 636-643.

Uzoechi, L. I. (2015). Assessment of employability skills acquisition among university students in Imo state, Nigeria. An M.Ed thesis, University of Calabar.

https://www.malaymail.com/news/malaysia/2021/03/12/ higher-education-ministry-malaysian-graduatesemployability-down-to-84.4pc/1957347)

https:/www.nst.com.my/news/nation/2020/02/566731/ graduate-employability-priority-education-ministry 